\title{
Preliminary contribution to a revision of the Chilean Cerato- canthinae (Coleoptera Hybosoridae) with description of two new species of Martinezostes Paulian, 1982
}

\author{
Alberto Ballerio' \& José Mondaca² \\ 1Viale Venezia 45, 25123 Brescia, Italy; e-mail: alberto.ballerio.bs@aballerio.it \\ ${ }^{2}$ Servicio Agrícola y Ganadero (SAG), camino La Pólvora Km 12, Valparaíso, Chile; e-mail: jose.mondaca@sag.gob.cl
}

\begin{abstract}
Two new species of Ceratocanthinae (Coleoptera Hybosoridae) from Central Chile are described, i.e. Martinezostes barrigai n. sp. and Martinezostes poqui n. sp. Remarks are provided on Martinezostes ruizi (Gutiérrez, 1946), a species which till now has been misinterpreted. A key to the new species is provided as well as images of habitus of the adults and the aedeagi.
\end{abstract}

KEY WORDS

Taxonomy; Neotropical region; Cerro Poqui; Altos de Vilches.

Received 12.01.2020; accepted 02.03.2020; published online 26.03.2020

\section{INTRODUCTION}

The fauna of Ceratocanthinae (Coleoptera Scarabaeoidea Hybosoridae) of Chile is currently comprised of four species ranged into two genera: Germarostes posticus (Germar, 1843) and Martinezostes asper (F. Philippi, 1859), M. fortecostatus (Gutiérrez, 1949) and M. ruizi (Gutiérrez, 1946) (Ocampo \& Ballerio 2006). These four species were keyed by Gutiérrez (1949). In his revision of South American Ceratocanthinae, Paulian (1982), while establishing the genus Martinezostes Paulian, 1982 was however unable to examine the types kept in Chilean collections, therefore his revision contains some mistakes and, as a result, some species have been misinterpreted. With the aim to clarify the diversity and distribution of the Ceratocanthinae in the area, a revision of the Chilean fauna is in progress, which will also assess the validity of the genus Martinezostes and the generic placement of G. posticus. The purpose of this preliminary note is to describe two new species, which are placed in the genus Martinezostes.

\section{MATERIAL AND METHODS}

Methods and terminological conventions follow Ballerio \& Grebennikov (2016) and references therein quoted. Label data are provided verbatim, with a slash to separate labels for holotypes only. Photographs of the habitus were taken with a Canon Eos D5 MII with a macro objective MP $65 \mathrm{~mm}$, while photographs of the male genitalia were taken with a Canon Eos D5 MII connected with a phototube to a Leica MZ 12.5 stereoscope. Multi-layer images were then assembled using Helicon Focus software and cleaned and unmasked using a photo processing software. Geographic coordinates of the collecting sites where recorded using Google Earth Pro. The distribution map was generated with www.simplemappr.net.

ABBREVIATIONS AND ACRONYMS. EL: maximum elytral length; EW: maximum total ely- 
tral width; HL: maximum head length; HW: maximum head width; L: length; PL: maximum pronotal length at middle; PW: maximum pronotal width at middle; $\mathrm{W}$ : width.

ABCB: Alberto Ballerio collection, Brescia, Italy. BMNH: The Natural History Museum collection, London, United Kingdom. FMNH: Field Museum of Natural History collection, Chicago, U.S.A. FRFC: Francisco Ramírez collection, Santiago, Chile. JMEC: José Mondaca collection, Villa Alemana, Chile. MNNC: Museo Nacional de Historia Natural collection, Santiago, Chile. MZUC: Museo de Zoología collection, Universidad de Concepción, Concepción, Chile. JEBC: Juan Enrique Barriga collection, Curicó, Chile.

\section{RESULTS}

\section{Systematics}

Martinezostes barrigai n. sp. - Figs. 1-5, 16, 19, 21 - http://zoobank.org/2683 acbf-cc23-4aaeb9b5-e0eddeb4d9e4

Examined material. Type series. Holotype male in MNNC: / ALTO VILCHES Prov. Talca 13, 18-Nov. 1972 / Coll: L. Alvarez L. Cartagena / Holotype male Martinezostes barrigai n. sp. des. Ballerio \& Mondaca /. Paratypes (27 specimens): 1 (MNNC): Alto Vilches - Prov. Talca, 13, 18-Nov1972, coll: L. Alvarez / L. Cartagena; 2 (1 JMEC, 1 MNCC): Chile - Reg. Maule, Altos de Vilches, 25/29.I.2006, col. C. Fortino; 1 (JMEC): Chile, Prov. Talca, Altos de Vilches 1200 m, 2.XII.1999, col. M. Guerrero; 2 (1 JMEC, 1 MNNC): Chile, Reg. Maule, Altos de Vilches, 17.XII.2006, col. P. Pinto; 2 (JMEC): Provincia de Talca, Vilches Alto, 2.XI.2012, leg. Carlos Vidal; 3 (CJME): Chile, Reg. Maule, Altos de Vilches, 21.XI.2014, col. G. Aceituno; 1 (FRFC): Altos de Vilches, Talca, VII Reg., 28-NOV-1997, 1400 mts, leg. F. Ramírez; 1 (ABCB) (elytra only): Chile - Talca: Vilches Alto, Pantano de Vilches, 5.I.2014, leg. A. Ballerio; 1 (JEBC): Chile: Vilches Alto, Talca, 1200 mts., 1929.XII.1972, coll. P. Vidal; 1 (JEBC): Malcho - Parral, Linares - Chile, 10.XI.93; 2 (JEBC): Chile prov. Curicó, $20 \mathrm{KM} \mathrm{E}$. Potrero Grande, El Relvo, $25 \mathrm{mar}$ 2004 (pitfall), leg. J.E. Barriga, S $36^{\circ} 11^{\prime} 1^{\prime \prime}$ W70 56'1; 1 (FMNH): Prov. Talca, Alto Vilches, 17-24 de octubre de 1964, coll. L.E. Peña; 4 (FMNH):
Vilches Alto, Talca, 1200 mts. / 19-29.XII.1972, coll. P. Vidal (ex coll. Peña); 1 (BMNH): Talca, Altos de Lircay, 21-30.XI.2003; 4 (1 MNNC, 3 ABCB): Chile, Reg. Maule, Altos de Vilches, 11.XII.2016, col. G. Aceituno.

Diagnosis. Because of the combination of wrinkled pronotum and wide and smooth interstriae, lacking any pseudostriae, this new species of Martinezostes can be mistaken only with $M$. ruizi. It differs from $M$. ruizi in having the striae which are more regular (almost straight and continuous), whereas in M. ruizi they are more irregular. Moreover, the proximal and median third of elytra of M. barrigai $\mathrm{n}$. sp. (including the humeral area) has some irregular weak tubercles on the interstriae, whereas in M. ruizi all tubercles are limited to the distal third of elytra (where they are less developed than in M. barrigai n. sp.) or to the striae beyond the sixth.

DESCRIPTION. HL $0.75 \mathrm{~mm}$; HW: $1.51 \mathrm{~mm}$; PL: $1.70 \mathrm{~mm}$; PW: $2.75 \mathrm{~mm}$; EL: $3.10 \mathrm{~mm}$; EW: 2.75 $\mathrm{mm}$. Medium sized flightless Ceratocanthinae. Body moderately convex, dorsum glabrous (20x), shiny, black; underside, tarsi and antennae reddishbrown, setation yellowish. Head: W/L ratio= 2.01; fore margin irregularly arcuate, with apex blunt and obtuse; genae not aligned to fore margin, slightly produced outwards, rounded; genal canthus short, intruding the eye only for one sixth of ocular length; dorsal ocular area large (interocular distance about five times the maximum width of the dorsal ocular area), ventral ocular area about as large as dorsal ocular area. Head surface unevenly sculptured; disc with a slightly raised wide smooth tubercle, vertex with a slightly raised irregular-V-shaped smooth process; surface sculpturing with small irregular dense wrinkles. Pronotum: subtrapezoidal, relatively wide $(\mathrm{W} / \mathrm{L}$ ratio $=1.54)$, fore angles broadly triangular, fore margin and base distinctly beaded; sides of pronotum marked by a blunt carina ending in correspondence with the humeral angle of elytra; pronotum regularly convex; the whole surface covered by dense deep short wrinkles. Scutellum: a little longer than wide; apex sharp and acute, with distal third narrow, each side slightly curved inward; sides of base notched by articular process of elytron; surface covered by deep comma-shaped punctures. Elytra: longer than wide $(\mathrm{W} / \mathrm{L}$ ratio $=$ 0.85 ); moderately convex, outline (dorsal view) rel- 
atively elongate-oval, surface with more than ten fine shallow longitudinal regular striae, interstriae wide and smooth with very fine sparse simple punctation and with some irregular weak carinae and/or tubercles on discal portion, apical third of interstriae with strongly raised irregular tubercles or short carinae. Epipleura marked by a strong serrated bead with serrations very widely spaced, distal and median area between longitudinal interstria and epipleuron broadly furrowed. Wings absent (apterous). Antennae short, ten-segmented, scape relatively short, strongly securiform, pedicel rounded, slightly bent forward, funicle short, segments noticeably wider than long, club as long and almost as wide as funicle, three-segmented, segments small and setose, apart from the outer face of the first segment, which is almost glabrous. Protibiae with outer side with two strong outer apical teeth plus some basal smaller denticles. Apical spur of protibiae slender, short with tip acute and slightly bent downwards. Mesotibiae relatively slender, outer side strongly serrated, bearing regularly spaced strong short setae, outer face rugose: covered by several longitudinal to slightly transverse fine lines, apical edge completely covered by a sparse short setation and bearing two sexually dimorphic apical spurs near inner apical angle. Metatibiae relatively slender, slightly triangular, ending with two short, straight apical spurs, sides bearing regularly spaced strong short setae, outer face smooth apart from some longitudinal to slightly transverse fine lines. Expanded apical truncation small. Ventral side of tarsi (with the exception of the last tarsomere) with tufts of short setae. Sexual dimorphism: males have the inner apical spur of mesotibiae distinctly bent inwards, while in the female both apical spurs are straight. Male genitalia (Figs. 16, 19): aedeagus with parameres laterally flattened, relatively short and strongly sclerotized, very slightly asymmetrical; basal piece slightly twisted and longer than parameres.

VARIABILITY. The type series is quite variable in the sculpturing of elytra, whose interstriae show a strong variability as to the number and development of tubercles. The punctation of head and pronotum is also variable with pronotal disc having sometimes sparser wrinkles.

Etymology. Noun in the genitive case. Patronymic to honor Juan Enrique Barriga (Los Niches-Curicó, Chile), who collected many specimens of this new species.
Distribution And Biology. Known only from the pre-mountainous area of the Maule Region: Potrero Grande (Curicó), Altos de Vilches (Talca) and Malcho (Parral). This species lives in forests of "coigue" Nothofagus dombeyi (Mirb) Oerst. and "roble" N. obliqua (Mirb) Oerst. (Nothofagaceae), with an undergrowth composed of herbaceous plants and medium-height shrubs typical of the Maulino forest of central-south Chile (Fig. 5). The average annual rainfall in these locations ranges from 1100 to $1800 \mathrm{~mm}$, usually with an abundant snowfall from June to October. Adults of $M$. barrigai were collected during the day under dead logs of Nothofagus or under its bark, while at night it was possible to observe them walking actively on trunks located in the wettest sectors of the forest. An easy way to obtain adults of this species is by using unbaited pitfall traps (Barber traps) placed under the leaves accumulated on the ground next to the dead logs.

Martinezostes poqui n. sp. - Fig. 6-10, 17, 20, 21 - http://zoobank.org/44426b3d-763c-4b64b2b1-2619e40fd952

ExAmined MATERIAL. Type series. Holotype male in MNNC: / CHILE Cachapoal Cerro Poqui (Base ladera sur) $416 \mathrm{msnm} 34^{\circ} 12^{\prime} 40.4^{\prime \prime} \mathrm{S}$, 7103'21.0"O 30 agosto - 29 sept. 2016 Trampa pitfall leg. M Elgueta / Holotype male Martinezostes poqui n. sp. des. Ballerio \& Mondaca /. Paratypes (62 specimens): 12 (ABCB): Chile O'Higgins: Cerro Poqui, 24.VIII.2015 tramo. J. Mondaca \& A. Ballerio; 2 (in etanol) (MNNC): Chile, Reg. O'Higgins, Coltauco, Cerro Poqui, 15.V.2016, col. M. Guerrero. 15 (in etanol) (11 MNNC, 4 ABCB): Chile, Reg. O'Higgins, Cerro Poqui, Doñihue, 3.IX.2015, $520 \mathrm{mts}$, $34^{\circ} 12.38^{\prime} \mathrm{S}$, $71^{\circ} 03.74$ 'W, col. T. Fichet; 2 (JMEC): Cerro Poqui (Doñihue), Región del Gral. B. O'Higgins, $\mathrm{S} 34^{\circ} 12.38, \mathrm{~W} 71^{\circ} 03.74,520 \mathrm{~m}, 17 . \mathrm{X} .2015$, col. Thomas Fichet; 4 (JMEC): Chile, Reg. B. O'Higgins, Cerro Poqui, 21.X.2013, col. J. Mondaca E.; 5 (JMEC): Chile, Cachapoal, Cerro Poqui, 24.VIII.2015, col. J. Mondaca E.; 1 (JMEC): Chile, O'Higgins, Cerro Poqui, 8.I.2015, col. T. Fichet; 3 (JMEC): Chile, Cachapoal, Apalta, 10.VIII.2019, col. C. Pineda; 3 (FRFC): Cerro Poqui, Coltauco, VI Reg. 500 m, 22/23.VII.2012, leg. F. Ramírez; 1 (FRFC): Rangue, Laguna de Aculeo, Santiago, 07.VII/01.VIII.2014, leg. F. Ramírez; 2 (FRFC): 
Chile, Prov. Maipo, Rangue, El Cepillo, 27.VII.2010, col. J. Mondaca E.; 10 (MNNC): Chile, Cachapoal, Cuesta R.N. Loncha, $596 \mathrm{msnm}$, $34^{\circ} 11.148 \mathrm{~S}, 70^{\circ} 56.842 \mathrm{~W}, 14$ agosto-29 agosto 2018, Trampa caída 1, musgo, M. Elgueta y J. Solervicens; 3 (MNNC): Chile, Cachapoal, NE de Lo Moscoso, $872 \mathrm{msnm}, 34^{\circ} 34^{\prime} 15.1^{\prime \prime} \mathrm{S}, 71^{\circ} 04^{\prime} 40.8^{\prime \prime} \mathrm{O}$, 21 octubre -15 nov. 2016, Trampa pitfall 2. leg. M. Elgueta; 3 (MNNC): Chile, Cachapoal, Cerro Poqui, (Base ladera sur), $476 \mathrm{msnm}, 34^{\circ} 12^{\prime} 32.0^{\prime \prime} \mathrm{S}$, 71 03 '23.3”'O, 20 octubre -21 nov. 2016, Trampa pitfall, leg. M. Elgueta.

Diagnosis. Within the Chilean fauna $M$. poqui can be mistaken only with Germarostes posticus (Fig. 22) because of the simple punctation of pronotum (all other known Chilean Ceratocanthinae have wrinkled pronotum). It differs from G. posticus because of the wider pronotum (W/L ratio $=1.90 \mathrm{vs}$. 1.64 in G. posticus), as well as because of the striae, which are continuous and not interrupted several times (as in G. posticus) and the sculpturing of the apical third of elytra, which in $M$. poqui bears several strong tubercles, which are less developed in G. posticus.

DESCRIPTION. HL $0.55 \mathrm{~mm}$; HW: $1.38 \mathrm{~mm}$; PL: $1.50 \mathrm{~mm}$; PW: $2.06 \mathrm{~mm}$; EL: $3.18 \mathrm{~mm}$; EW: 2.88 $\mathrm{mm}$. Medium sized flightless Ceratocanthinae. Body moderately convex, dorsum glabrous (20x), shiny, black; underside, tarsi and antennae reddishbrown, setation yellowish. Head: W/L ratio= 2.50; fore margin irregularly arcuate, with apex blunt and obtuse; genae not aligned to fore margin, slightly produced outwards, rounded; genal canthus short, intruding the eye only for one sixth of ocular length; dorsal ocular area large (interocular distance about five times the maximum width of the dorsal ocular area), ventral ocular area about as large as dorsal ocular area. Head surface unevenly sculptured; disc with a slightly raised smooth tubercle; surface sculpturing with irregular relatively dense commashaped punctures with curvature inwards. Pronotum: subtrapezoidal, very wide $(\mathrm{W} / \mathrm{L}$ ratio $=1.90)$, fore angles broadly triangular, fore margin and base distinctly beaded; sides of pronotum marked by a blunt carina ending in correspondence with the humeral angle of elytra; pronotum regularly convex; the whole surface, apart from sides and base, covered by dense simple relatively shallow punctation; sides covered by sparser comma-shaped punc- tures mixed to few horseshoe-shaped punctures. Scutellum: a little longer than wide; apex sharp and acute, with distal third narrow, each side slightly curved inward; sides of base notched by articular process of elytron; surface with some commashaped punctures. Elytra: slightly longer than wide $(\mathrm{W} / \mathrm{L}$ ratio $=0.93)$; moderately convex, outline (dorsal view) oval, surface with more than ten fine shallow longitudinal irregular striae, interstriae wide and smooth with some irregular small strong tubercles on distal third. Sides of elytra with several longitudinal small irregular carinae. Epipleura marked by a strong serrated bead with serrations very widely spaced, distal and median area between longitudinal interstria and epipleuron broadly furrowed. Wings absent (apterous). Antennae short, ten-segmented, scape relatively short, strongly securiform, pedicel rounded, slightly bent forward, funicle short, segments noticeably wider than long, club as long and almost as wide as funicle, three-segmented, segments small and setose, apart from the outer face of the first segment, which is almost glabrous. Protibiae with outer side with two strong outer apical teeth plus some basal smaller denticles. Apical spur of protibiae slender, short with tip acute and slightly bent downwards. Mesotibiae relatively slender, outer side strongly serrated, bearing regularly spaced strong short setae, outer face rugose: covered by several longitudinal to slightly transverse fine lines, apical edge completely covered by a sparse short setation and bearing two sexually dimorphic apical spurs near inner apical angle. Metatibiae relatively slender, slightly triangular, ending with two short straight apical spurs, sides bearing regularly spaced strong short setae, outer face smooth apart from some longitudinal to slightly transverse fine lines. Expanded apical truncation small. Ventral side of tarsi (with the exception of the last tarsomere) with tufts of short setae. Sexual dimorphism: males have the inner apical spur of mesotibiae distinctly bent inwards, while in the female both apical spurs are straight. Male genitalia (Figs. 17, 20): aedeagus with parameres laterally flattened, relatively short and strongly sclerotized, very slightly asymmetrical; basal piece slightly twisted and longer than parameres.

VARIABILITY. The type series is quite variable in the size, since the total length ranges from 5 to 7 $\mathrm{mm}$ and this is relatively unusual for Ceratocanthi- 
nae, where the variation in length is normally feeble. The sculpturing of apical third of elytra is also variable in the shape and number of tubercles.

Eтymology. Noun in apposition. The name refers to the type locality.

DisTRIBUTION AND HABiTAT. Known only from localities in the coastal mountain range of the Santiago Metropolitan region and O’Higgins region. Martinezostes poqui $\mathrm{n}$. sp. lives in forests of "hualo" Nothofagus glauca (Phil.) Krasser and "roble de Santiago" N. macrocarpa (A.DC.) F. M.Vázquez \& R.A. Rodr. (Nothofagaceae), mixed with a sclerophyll vegetation typical of the Maulino forest of central Chile (Fig. 10). The average annual rainfall is $663 \mathrm{~mm}$, concentrated from June to $\mathrm{Au}$ gust. The Cerro Poqui sector is included in the priority conservation site called "La Roblería / Cordillera de la Costa Norte y Cocalán". For collecting circumstances see under M. barrigai $\mathrm{n}$. sp.

Martinezostes ruizi (Gutiérrez, 1946) - Fig. 11$15,18,21)$

EXAMINED MATERIAL. Holotype male in MNNC: / Holotypo / Curicó IV-1939 N.N. Coll. / Chile / Sud - America / Cloeotus ruizi Gutierr. R. Gutiérrez det. 47 /; Paratype (MZUC): Curicó IV.1939 N.N. Coll.; Non typical material: 1 male (JEBC): Chile, Prov. Curicó, Romeral-Los Queñes, I.1981, leg. J. E. Barriga; 1 (JEBC): Chile, Prov. Curicó, Romeral Los Queñes, ene. 1981, leg. J.E. Barriga; 1 (JMEC): Chile, Prov. Maipo, Rangue-El Cepillo, 27.VII.2010, col. J. Mondaca E.; 2 (JMEC): Chile, B. O'Higgins, Cerro Poqui, 21.X.2013, col. J. Mondaca E.; 1 (JMEC): Chile, Colchagua, Alto Huemul, 21.XI.2001，J. Mondaca E.; 1 (JMEC): Alto Huemul, San Fernando, VI reg., 22.IV.2000, col. M. Gálvez A.; 1 (JMEC): Chile, Prov. Cachapoal, Cerro Poqui, 5.X.2013, leg. Carlos Vidal; 3 (ABCB): Chile, Reg. O'Higgins, Cerro Poqui, Doñihue, 3.IX.2015, $520 \mathrm{mts}, \quad 34^{\circ} 12.38^{\prime} \mathrm{S}$, 7103.74'W; 1 (JMEC): Chile, Cachapoal, Cerro Poqui, 3.IX.2015, col. Th. Fichet; 2 (MNNC): Chile, Cachapoal, Cerro Poqui (Base ladera sur),

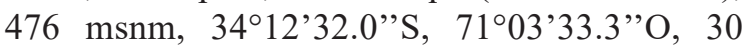
agosto - 29 sept. 2016, Trampa pitfall, leg. M. Elgueta; 1 (MNNC): Chile, Colchagua, E Lo Moscoso, $465 \mathrm{msnm}, 33^{\circ} 26.146^{\prime} \mathrm{S}, 70^{\circ} 50.789^{\prime} \mathrm{W}$,
25 septiembre-18 octubre 2018, trampa caída, musgo, M. Elgueta y J. Solervicens; 1 (MNNC): Chile, Colchagua, E Lo Moscoso, $872 \mathrm{msnm}$, $33^{\circ} 34^{\prime} 15.1^{\prime \prime} \mathrm{S}, \quad 71^{\circ} 04^{\prime} 40.8^{\prime \prime} \mathrm{W}, 21$ octubre-15 noviembre 2016, trampa pitfall, leg. M. Elgueta.

DisTRIBUTION AND HABITAT. Known from various localities in the coastal mountain range and in the Andes mountain range of Central Chile: Rangue - El Cepillo and Laguna de Aculeo (Región Metropolitana de Santiago), Cerro Poqui, Lo Moscoso, and Alto Huemul (Región de O'Higgins), Curicó and Romeral - Los Queñes (Región del Maule). Martinezostes ruizi lives in forests of "coigüe" Nothofagus dombeyi (Mirb.) Oerst., "roble" N. obliqua (Mirb.) Oerst. (in Maule mountain range), "hualo" N. glauca Phil. Krasser and "roble de Santiago" N. macrocarpa (in coastal mountain range), mixed with sclerophyll vegetation characteristic of central-southern Chile. The average annual rainfall in these places increases from north to south, from $431 \mathrm{~mm}$ (Laguna de Aculeo) to $1194 \mathrm{~mm}$ (Los Queñes), the latter area experiences abundant snowfall from June to October. For collecting circumstances see under $M$. barrigai n. sp.

ReMARKS. Martinezostes ruizi has been misinterpreted till now probably due to the circumstance that Paulian (1982), while revising the South American fauna of Ceratocanthinae, did not examine the type material of this species. As a result both the specimens attributed to $M$. ruizi and illustrated respectively by Paulian (1982: plate X fig. a) and by Howden \& Gill (2000: fig. 28) do not match the holotype of $M$. ruizi (and the description by Gutiérrez) and are representatives of other species falling within the asper/fortecostatus group of species, i.e. the Martinezostes species having the elytral interstriae divided into many pseudostriae. Conversely the true $M$. ruizi has wide smooth interstriae and is closely related to $M$. barrigai $\mathrm{n}$. sp. from which it differs because of the characters listed in the diagnosis of the new species. Gutiérrez's collection is kept in MZUC and MNNC. In Gutiérrez collection several type locality labels do not exactly match the collecting records that Gutiérrez published in his papers. One such example is M. ruizi: Gutiérrez in the 1946 paper lists only one specimen ("Tipo") coming from "Curicó. Zona maritima" "I-35". In MNNC we found the 


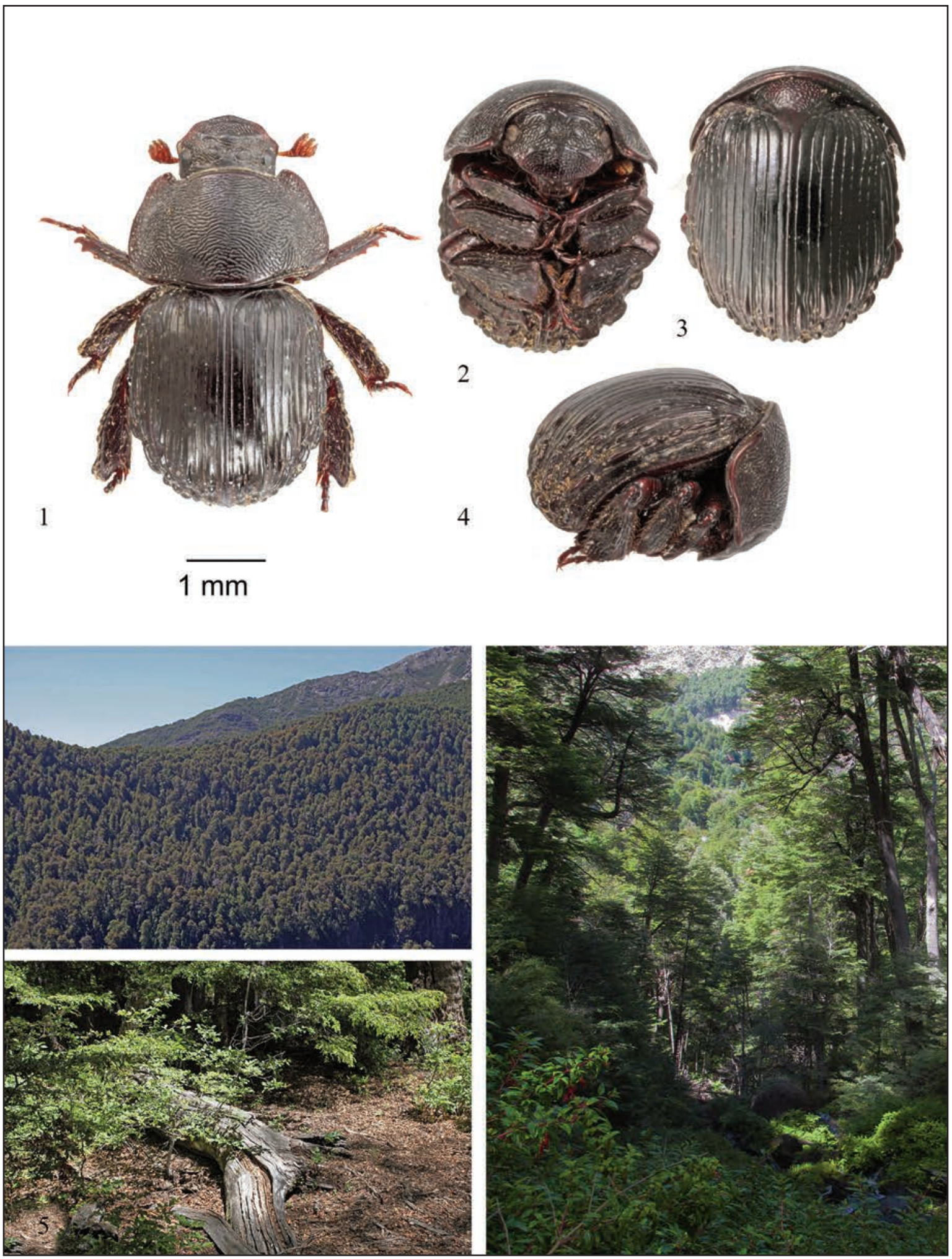

Figures 1-4. Martinezostes barrigai n. sp. Fig. 1: distended paratypus (Malcho - Parral), dorsal view. Fig. 2: rolled up paratypus (Altos de Vilches), ventral view. Fig. 3: rolled up paratypus ((Altos de Vilches), dorsal view. Fig. 4: rolled up paratypus (Altos de Vilches), lateral view. Figure 5. Martinezostes barrigai n. sp.: photos of type locality (top left: Altos de Vilches, Nothofagus forest, bottom left: Pantano de Vilches, Nothofagus forest understorey, right: Altos de Vilches, Nothofagus forest). 


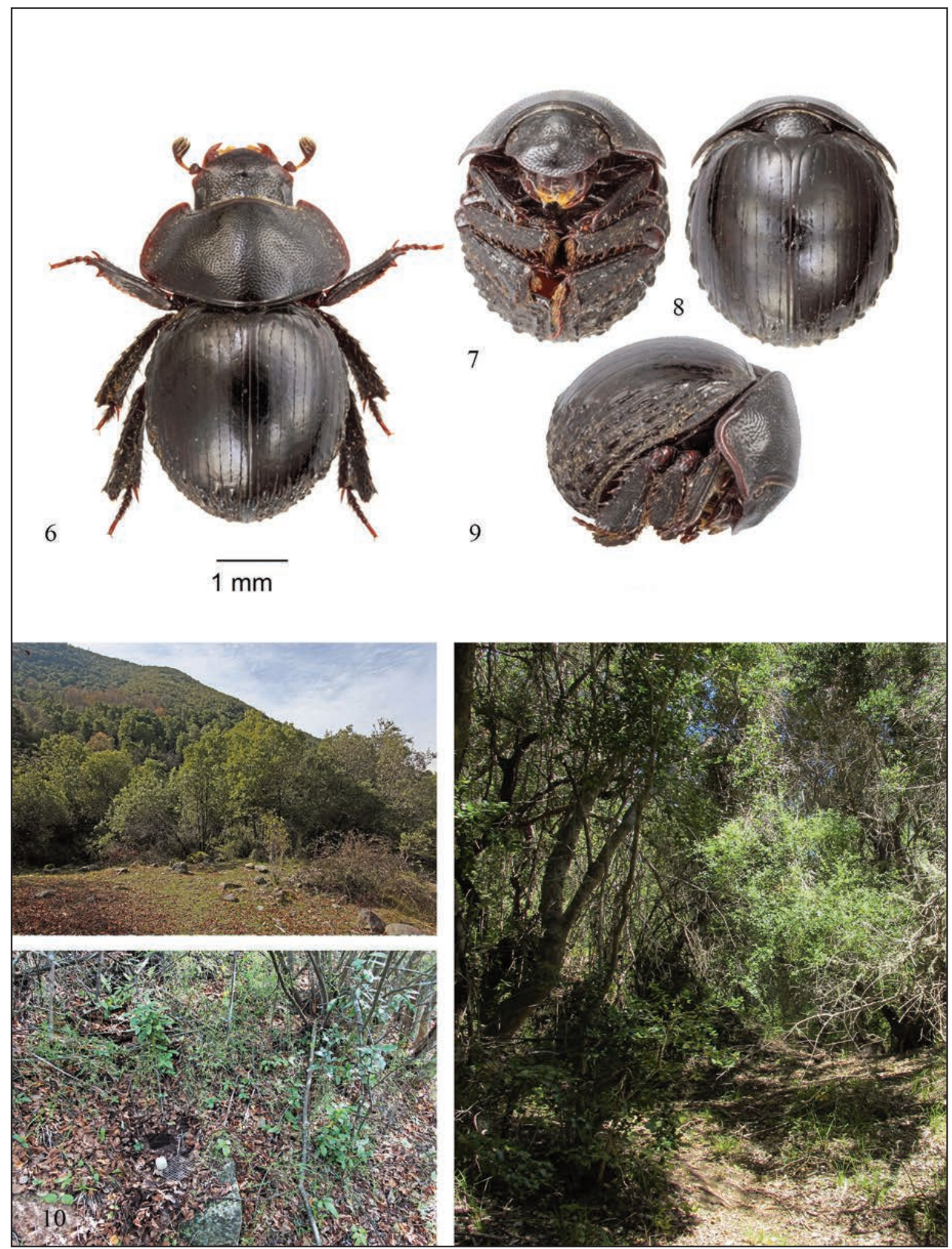

Figures 6-9. Martinezostes poqui n. sp. (Cerro Poqui). Fig. 6: distended paratypus, dorsal view. Fig. 7: rolled up paratypus, ventral view. Fig. 8: rolled up paratypus, dorsal view. Fig. 9: rolled up paratypus, lateral view. Figure 10. Martinezostes poqui n. sp.: photos of type locality (top left: Cerro Poqui, bottom left: pitfall trap in Cerro Poqui, right: Cerro Poqui). 


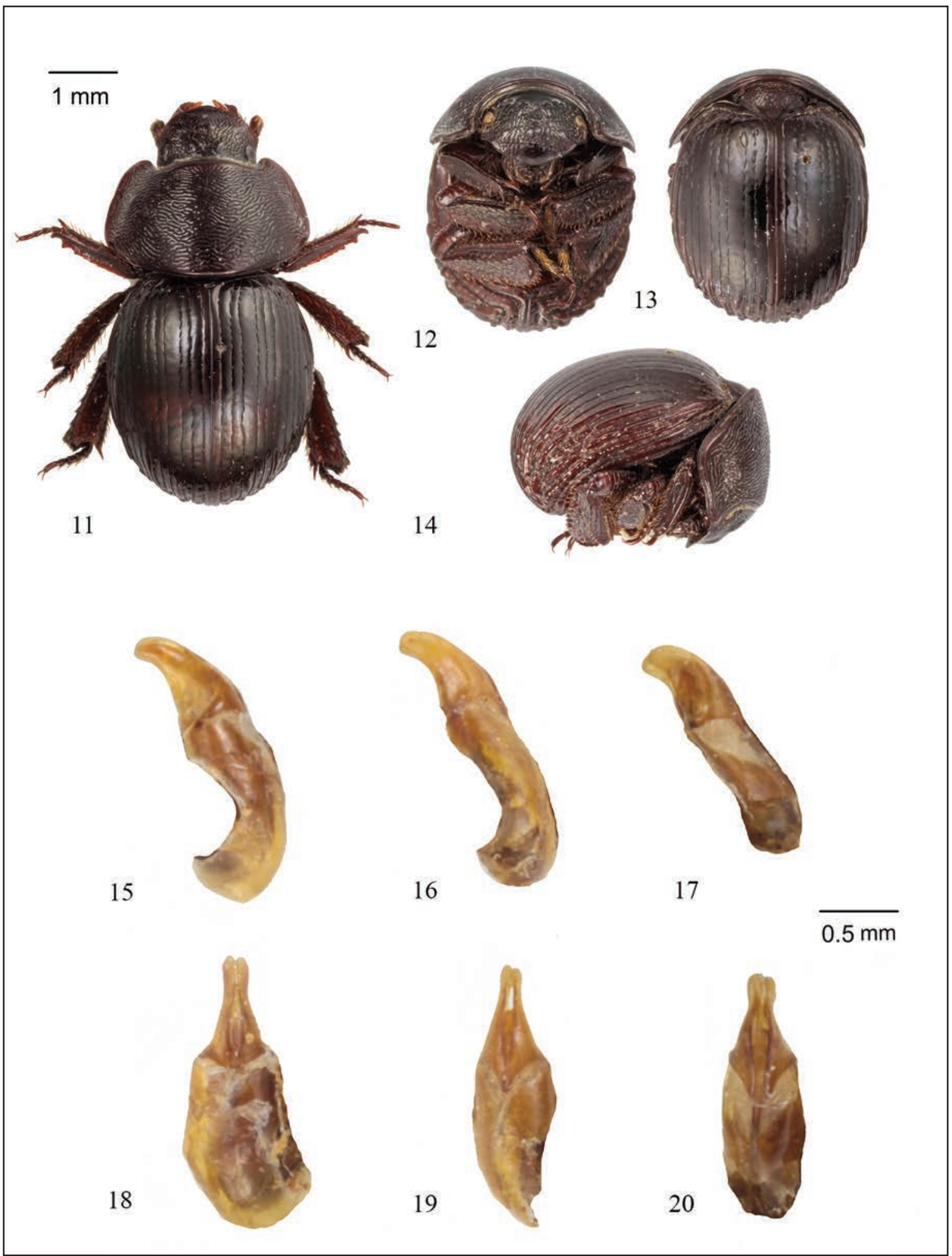

Figures 11-14. Martinezostes ruizi (Gutiérrez, 1946) (Cerro Poqui). Fig. 11: distended specimen, dorsal view. Fig. 12: rolled up specimen, ventral view. Fig. 13: rolled up specimen, dorsal view. Fig. 14: rolled up specimen, lateral view. Figures 1520. Aedeagi in lateral and dorsal view. Figs. 15, 18: M. ruizi (Gutiérrez, 1946). Figs. 16, 19: Romeral Los Queñes, $M$. barrigai n. sp. (Altos de Vilches). Figs. 17, 20: M. poqui n. sp. (Cerro Poqui). 
holotype, i.e., a specimen bearing the label "HOLOTIPO" (see Material examined above) although the date does not match the date indicated by Gutiérrez in the original description but we deem that this is due to a mistake made during the labeling of type material. Although Gutiérrez in the original description of $M$. ruizi mentioned only the holotype, later he gave evidence of having examined two specimens, bearing the same locality and date label (Gutiérrez, 1949). Actually we found the above mentioned paratype in MZUC. Therefore, under art. 72.4.1.1 of the Code, we can conclude that the type series of $M$. ruizi is composed of the holotype in MNNC and one paratype in MZUC, as listed under material examined above. It must be finally noticed that Cekalovic \& Artigas (1969), while listing the types in MZUC made probably a mistake by inverting the records, since they listed a paratype from Valdivia under M. ruizi (sub Cloeotus ruizi) and a paratype from Curicó under M. fortecostatus (sub Cloeotus fortecostatus whose type comes from Valdivia).

\section{Key for the identification of the new species here described within Chilean fauna}

1. Pronotal sculpturing made of simple punctation.

- Pronotal sculpturing made of transverse irregular wrinkles

2. Elytral striae shallow and continuous. Pronotum wide $(\mathrm{W} / \mathrm{L}$ ratio $=1.90)$, distal third of elytra with sparse distinctly raised tubercles.

M. poqui n. sp. (Fig. 3)

- Elytral striae deep and regularly interrupted (consisting of rows of elongate punctures especially on proximal third). Pronotum narrower $(\mathrm{W} / \mathrm{L}$ ratio $=$ 1.65), distal third of elytra with interstriae more raised than on elytral medial and proximal third, sometimes giving rise to some weak tubercles

G. posticus (Germar, 1843) (Fig. 22)

3. Elytral interstriae divided into many pseudostriae.................asper/fortecostatus group of species - Elytral interstriae smooth (only some sparse simple fine punctation visible).

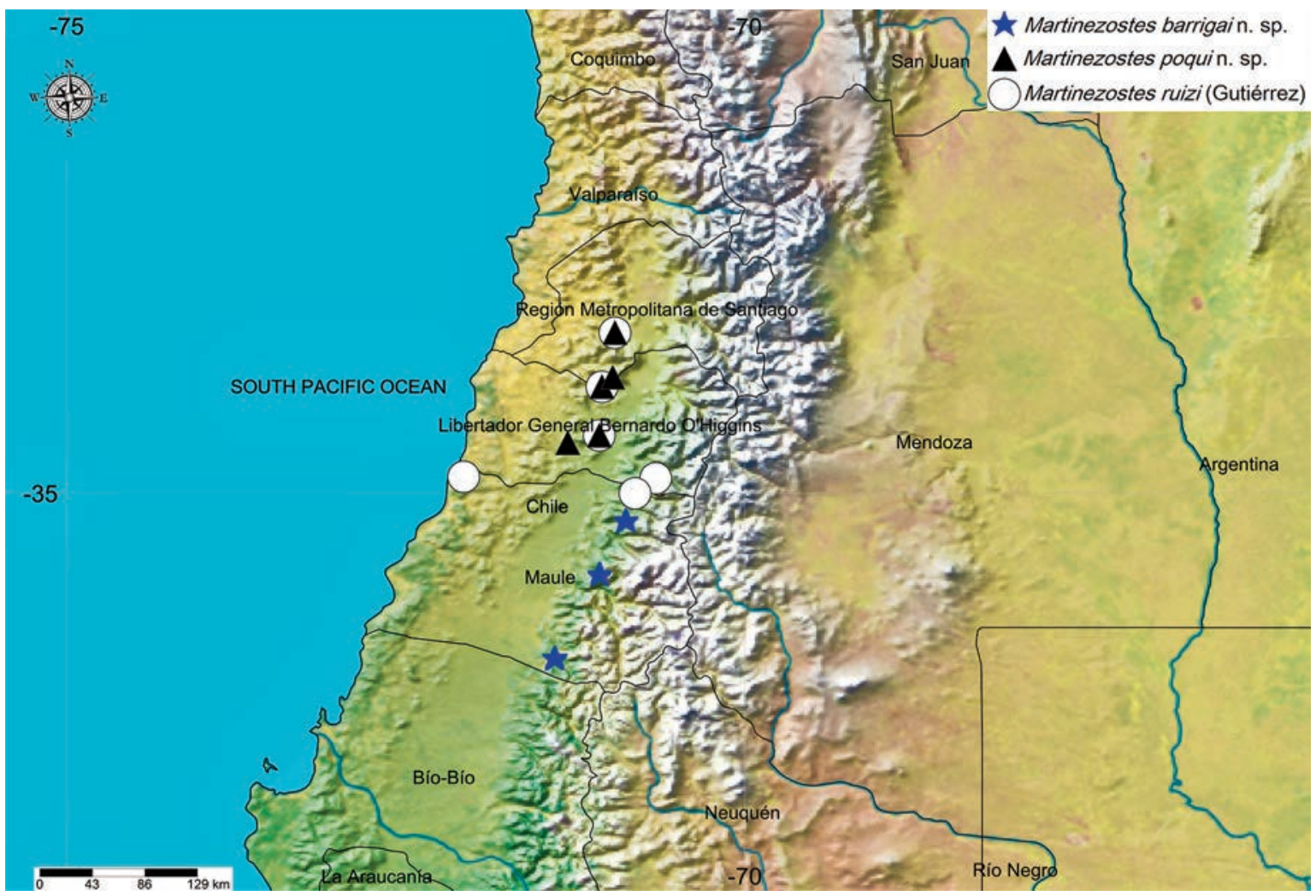

Figure 21. Distribution map: Martinezostes ruizi (Gutiérrez, 1946) (white circles), M. barrigai n. sp. (blue stars) and M. poqui n. sp. (black triangles). 


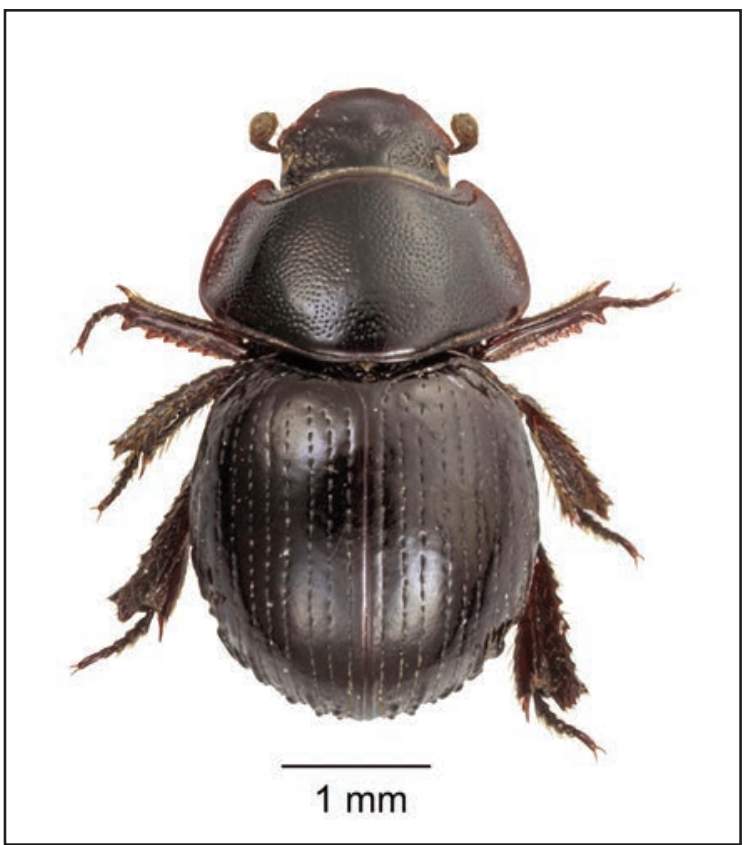

Figure 22. Germarostes posticus (Germar, 1843): distended specimen from La Campana National Park (Valparaíso).

4. Elytral striae straight, elytral interstriae with few sparse irregular weak tubercles on proximal and median third, distal elytral tubercles larger and strongly raised M. barrigai n. sp. (Fig. 1) - Elytral striae irregularly longitudinal, elytral interstriae smooth on proximal and median third, distal elytral tubercles smaller and less strongly raised M. ruizi (Gutiérrez, 1946) (Fig. 5)

\section{ACKNOWLEDGEMENTS}

We would like to thank Marcelo Guerrero, Carlos Vidal, Pablo Pinto, Cesar Fortino, Guillermo Aceituno, Thomas Fichet, Cristian Pineda and Francisco Ramírez and Jason Mate for providing us with specimens of the new species for study. We also thank Mario Elgueta (MNNC), Jorge Artigas
(MZUC), Maxwell V.L. Barclay (BMNH) and Alfred Newton (FMNH) for allowing us to examine the type material and/or other relevant specimens in the collections under their care. The trips of Alberto Ballerio to Chile were partly sponsored by the WBA ONLUS (Verona, Italy), which is here thanked.

\section{REFERENCES}

Ballerio A. \& Grebennikov V.V., 2016. Rolling into a ball: phylogeny of the Ceratocanthinae (Coleoptera: Hybosoridae) inferred from adult morphology and single origin of an unique body enrollment coaptation in terrestrial arthropods. Arthropod Systematics and Phylogeny, 74: 23-52.

Cekalovic T.K. \& Artigas J.N., 1969. Catalogo de los tipos de Insecta depositados en la coleccion del Departamento de Zoologia de la Universidad de Concepcion (INCO). Parte I. Boletín de la Sociedad de Biología de Concepción, 41: 111-133.

Gutiérrez R., 1946. Notas sobre Scarabaeidae chilenos. Livro de Homenagem a R.F. d'Almeida, 2: 11-16.

Gutiérrez R., 1949. Notas sobre Scarabaeidae neotropicos (Coleoptera Lamellicornia). Anales de la Sociedad Científica Argentina, 148: 9-35.

Howden H. F. \& Gill B.D., 2000. Tribes of New World Ceratocanthinae, with keys to genera and descriptions of new species (Coleoptera: Scarabaeoidea). Sociobiology, 35: 281-329.

Ocampo F.C. \& Ballerio A., 2006. Phylogenetic analysis of the scarab family Hybosoridae and monographic revision of the New World subfamily Anaidinae (Coleoptera: Scarabaeoidea). 4. Catalog of the subfamilies Anaidinae, Ceratocanthinae, Hybosorinae, Liparochrinae, and Pachyplectrinae (Scarabaeoidea: Hybosoridae). Bulletin of the University of Nebraska State Museum, 19: 178-209.

Paulian R., 1982. Révision des Cératocanthides (Coleoptera Scarabaeoidea) d'Amérique du Sud. Mémoires du Muséum National d'Histoire Naturelle (Ser. A, Zoologie), 124: 1-110. 